\title{
Characterization and Confirmation of Papaya ringspot virus-W Strain Infecting Trichosanthese cucumerina at Tamil Nadu, India
}

\author{
Kumar $\mathbf{S}^{1 *}$, Sankarlingam $\mathbf{A}^{2}$ and Rabindran $\mathbf{R}^{1}$ \\ ${ }^{1}$ Department of Plant Pathology, Tamil Nadu Agricultural University, Coimbatore, India \\ ${ }^{2}$ Department of Plant Pathology, Agricultural College and Research Institute Tamil Nadu Agricultural University, Madurai, India
}

\begin{abstract}
Mosaic and leaf blisters symptoms were observed in Trichosanthese cucumerina (Snake gourd) in regions of coimbatore, India. The biological, physical, serological and molecular properties of the virus isolate were studied. Virus isolate produce chlorotic local lesions on Chenopodium amaranticolor and systemic symptoms on all inoculated cucurbitaceous hosts. The particles appear flexuous rod shape of $750 \times 12 \mathrm{~nm}$ under electron microscope. Serologically this isolate identified as strain of PRSV. Dilution end point of virus isolate was $10-4$. Thermal inactivation point and Longevity in-vitro of the virus isolate was found to be $55^{\circ} \mathrm{C}$ and $30 \mathrm{~h}$ respectively.
\end{abstract}

Keywords: Gourds; Virology; PRSV-W; Host range; Cucurbits; Mosaic

\section{Introduction}

The Family cucurbitaceae comprises approximately 80 - genera and over 800 species of plants. Trichosanthese cucumerina L., locally known as snake gourd or serpent gourd is an important vegetable crop in this family which is probably of native of India. It is cultivated in subtropical and tropical areas [1].

Mosaic disease is the common in the cucurbitaceous crops. Several viruses has viz., Cucumber mosaic virus (CMV), cucumis virus-2, watermelon mosaic virus(WMV)-1, Papaya ringspot virus (PRSV)-w, Zucchini yellow mosaic virus (ZYMV), WMV-2 and Yellow vein mosaic of pumpkin infecting cucurbits have been reported from India, Nepal, Taiwan, Pakistan and Sri Lanka [2-7].

In the year 2009, the mosaic and leaf blistering symptoms observed in the Thondamuthur area and orchard, TNAU, Coimbatore, India. The samples were collected and studied for the virus identification. Biological, physical, serological and molecular behavior of the virus isolated was studied critically.

\section{Materials and Methods}

\section{Symptomatology, virus culture and its maintenance}

Leaves of snake gourd showing symptoms of mosaic, blistering vein thickening and leaf distortion were collected from the orchard, Tamil Nadu Agricultural University (TNAU), Coimbatore and Farmer's field in Thodamuthur, Coimbatore, and Tamil Nadu in 2008. These infected leaves were used as the source of inoculums.

Test seedlings rose in pots containing mixture of soil, sand and farm yard manure. Sap was prepared from infected leaves by grinding in a pre-chilled mortar and pestle with $1 \mathrm{M}$ sodium phosphate buffer $(\mathrm{pH} 7.2)$ at $1 \mathrm{ml} / \mathrm{g}$ of leaf. The sap was rub-inoculated on the 3-leaf stage seedlings, previously dusted with 600 mesh carborandum. After 5 min the excess sap was washed off with distilled water and plants were kept under insect proof cages for symptom expression.

\section{Host range}

The virus isolate maintained separately on snake gourd plants were sap inoculated to seedlings of different test plants pertaining to six families were used for host range studies.

\section{Electron microscopy}

One hundred mg of leaf tissue from artificially inoculated plants was macerated with $0.05 \mathrm{M}$ sodium phosphate buffer in the ratio of $1: 1(\mathrm{w} / \mathrm{v})$. The virus extract was centrifuged at $12,000 \mathrm{rpm}$ for $5 \mathrm{~min}$ and the supernatant was collected. One drop of this supernatant was placed on the surface of commercially available formvar coated copper grids. The grids were allowed to dry for $5 \mathrm{~min}$, washed gently with double distilled water and stained with $2 \%$ uranyl acetate. There after the excess stain was removed and the mounted grids were examined in a JEO JEM-1011 transmission electron microscope.

\section{Physical properties of the virus isolates}

Dilution end point (DEP): Serial dilution from infected leaves was prepared from $10^{-1}-10^{-8}$ by adding distilled water to the standard extract. The undiluted sap served as the control. Test plants were inoculated with mentioned diluted sap.

Thermal inactivation point (TIP): The TIP was determined by subjecting $2 \mathrm{ml}$ of the sap to temperatures viz., 35, 40, 45, 50, 55, 60 and $65^{\circ} \mathrm{C}$ for $10 \mathrm{~min}$ in a water bath. Freshly extracted sap that was not subjected to any temperature regime served as control.

Longevity in vitro (LIV): Sap from the infected leaves was divided into aliquots of $2 \mathrm{ml}$ in test tubes and stored at room temperature (28 \pm $2^{\circ} \mathrm{C}$ ). At $6,12,18,24,48 \mathrm{~h}$ interval the sap was inoculated on seedlings of the assay host. Freshly extracted sap was used as control.

\section{Serology}

Source of antisera: Antibodies for PRSV, CMV and TSV and their positive samples were provided by DSMZ, Braunschweing, Germany.

*Corresponding author: Kumar S, Department of Plant Pathology, Tamil Nadu Agricultural University, Coimbatore, India, Tel: +91-9900494422; E-mail: sushil.pareek2@gmail.com

Received: March 15, 2014; Accepted May 02, 2014; Published May 08, 2014

Citation: Kumar S, Sankarlingam A, Rabindran R (2014) Characterization and Confirmation of Papaya ringspot virus-W Strain Infecting Trichosanthese cucumerina at Tamil Nadu, India. J Plant Pathol Microb 5: 225. doi:10.4172/21577471.1000225

Copyright: ( 2014 Kumar S, et al. This is an open-access article distributed under the terms of the Creative Commons Attribution License, which permits unrestricted use, distribution, and reproduction in any medium, provided the original author and source are credited. 
Enzyme linked immunosorbant assay (ELISA): DAS-ELISA was performed for detection of the virus isolates following the manufacturer's instruction (DSMZ Gmbh, Braunschweig, Germany). Purified IgG was diluted in coating buffer (1:1000) and $200 \mu \mathrm{l}$ was added to each well of a microtiter plate. The plates were incubated at $37^{\circ} \mathrm{C}$ for $3 \mathrm{~h}$ and thereafter plates were washed with phosphate buffered saline- Tween (PBS-T), soaked for a few minutes and washing was repeated twice. Plates were tapped upside down on tissue paper. Aliquots of $200 \mu \mathrm{l}$ each of the test sample extracted in sample extraction buffer was added to wells in duplicate. Buffer without sample served as control and plates were incubated at $4^{\circ} \mathrm{C}$ overnight. The plates were washed as earlier and $200 \mu \mathrm{l}$ of the anti-virus conjugate (1:500) was added to each well and incubated at $37^{\circ} \mathrm{C}$ for $2 \mathrm{~h}$. later the plates were washed three times.

Finally $200 \mu \mathrm{l}$ of freshly prepared substrate (10 mg of $\rho$-nitro phenyl phosphate dissolved in $10 \mathrm{ml}$ of freshly prepared substrate buffer) was added to each well and incubated in dark at room temperature for 45 min or as long as necessary to obtain clear reactions. Spectrometric measurement of absorbance was read at $405 \mathrm{~nm}$ (EL 800, BIO-TEK Instrument Inc., USA) and the reaction was later arrested by adding 50 $\mu \mathrm{l}$ of $3 \mathrm{M} \mathrm{NaOH}$.

\section{Molecular characterization of the virus}

The coat protein gene of the viral genome was amplified by reverse transcription polymerase chain reaction (RT-PCR) for confirming the virus. Total RNA was extracted from infected and healthy leaf tissues with GeneiTM plant RNA isolation kit (Bangalore Genei Pvt. Ltd, Bangalore, India). The purity of RNA was checked by formaldehyde agarose gel electrophoresis.

RT and PCR were performed in two tubes. First strand cDNA synthesis was performed using Omniscript RT kit (Qiagen Inc., Chatsworth, CA, USA) according to the manufacturer's protocol. Resulting cDNA was stored at $-20^{\circ} \mathrm{C}$.

PCR product was amplified from the cDNA using primers specific to potyviruses re synthesized from 1st BASE Company (Agile Lifescience Technologies India Pvt. Ltd. Airoli, Navi Mumbai) in salt free status. Forward primer HRP4 5'TGG TGY ATH GAN AAT GG* 3' $\left({ }^{\star} \mathrm{Y}: \mathrm{C} / \mathrm{T}, \mathrm{H}: \mathrm{A} / \mathrm{T} / \mathrm{C}, \mathrm{N}: \mathrm{A} / \mathrm{G} / \mathrm{C} / \mathrm{T}\right)$ and reverse primer HRP1 (5' TTT TTT TTT TTT TTT TTT TTT A 3’), HRP2 (5’ TTT TTT TTT TTT TTT TTT TTT G 3'), HRP3 (5’ TTT TTT TTT TTT TTT TTT TTT C 3').

$25 \mathrm{ml}$ of reaction mixture containing $2.5 \mu \mathrm{l}$ of cDNA, 20 pmol each of forward and reverse primers, $200 \mathrm{mM}$ each of dNTPs, $2.5 \mu \mathrm{l}$ of $10 \mathrm{X}$ PCR buffer with $15 \mathrm{mM} \mathrm{MgCl}$ and 0.5 unit of Taq DNA polymerase (Bangalore Genei Pvt. Ltd, Bangalore, India) were used in PCR. The amplification was performed in a CR Palm cycler (Corbett Research, Australia). Temperature profile used in the amplification was as preincubation at $94^{\circ} \mathrm{C}$ for 5 min leading to 40 cycles of denaturation at $94^{\circ} \mathrm{C}$ for $1 \mathrm{~min}$, annealing at $42^{\circ} \mathrm{C}$ for $2 \mathrm{~min}$ and synthesis at $72^{\circ} \mathrm{C}$ for $90 \mathrm{sec}$. After amplification, the PCR products were electrophoreses in $1.5 \%$ agarose gel.

\section{Results}

\section{Symptomatology}

Mechanically inoculated seedlings of snake gourd expressed symptoms after 25 days of inoculation. Mosaic, leaf blistering and combinations of these symptoms were observed on leaves of snake gourd seedlings (Figure 1).

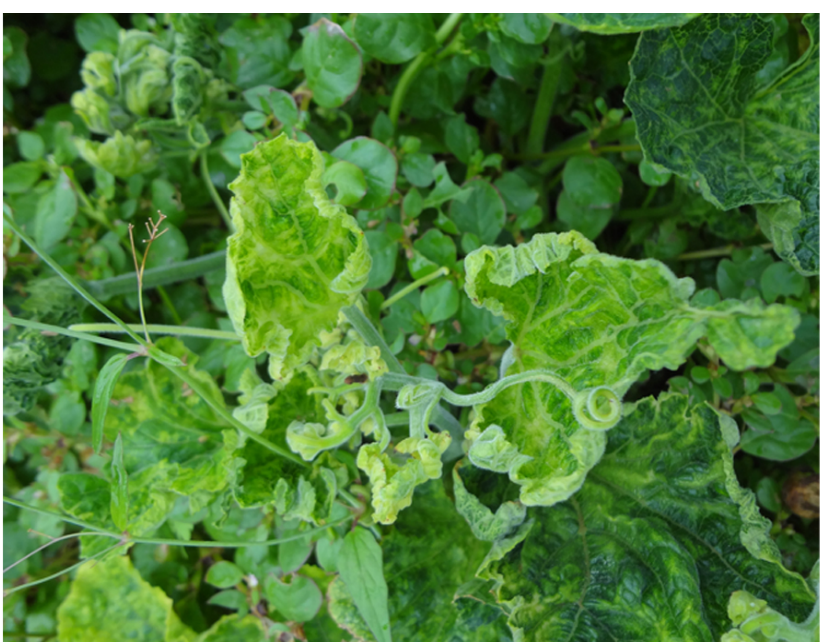

Figure 1: Field symptoms of PRSV-W on snake gourd leaves.

\begin{tabular}{|c|c|c|c|}
\hline Family & Plant species & $\begin{array}{l}\text { Stage of } \\
\text { inoculation }\end{array}$ & Symptoms \\
\hline Aizoaceae & Trianthema portulacastrum & $\begin{array}{l}\text { Lower 4-5 } \\
\text { leaves }\end{array}$ & NS \\
\hline \multirow[t]{2}{*}{ Amaranthaceae } & Gomphrena globosa & \multirow{2}{*}{4 leaf stage } & CS \\
\hline & Amaranthus viridis & & NS \\
\hline Caricaceae & Carica papaya & $\begin{array}{l}\text { 2-month-old } \\
\text { seedlings }\end{array}$ & NS \\
\hline \multirow[t]{2}{*}{ Chenopodiaceae } & Chenopodium amaranticolor & \multirow{2}{*}{$\begin{array}{l}\text { 5-6 leaf } \\
\text { stage }\end{array}$} & CS \\
\hline & Chenopodium album & & \\
\hline Compositae & Helianthus annuus (sunflower) & 4-leaf stage & NS \\
\hline \multirow[t]{6}{*}{ Cucurbitaceae } & Trichosanthes cucumerina (snake gourd) & \multirow{6}{*}{ 3-leaf stage } & MMo/LB/LD \\
\hline & Lagenaria siceraria (bottle gourd) & & MLB/DNT \\
\hline & Luffa acutangula (ridge gourd) & & $\mathrm{M} / \mathrm{CL}$ \\
\hline & Cucumis sativus (cucumber) & & M/LD \\
\hline & Cucurbita moscheta (pumpkin) & & M/LD \\
\hline & Cucumis melo (melon) & & M/LB \\
\hline \multirow[t]{5}{*}{ Fabaceae } & Vigna sinensis (cowpea) & \multirow{5}{*}{ 2-leaf stage } & NS \\
\hline & Vigna mungo (black gram) & & \\
\hline & Vigna radiata(green gram) & & \\
\hline & Dolichus lablab (lablab) & & \\
\hline & Phaseolus vulgaris (bean) & & \\
\hline Portulacaceae & Portulaca oleracea & $\begin{array}{l}\text { Lower 5-6 } \\
\text { leaves }\end{array}$ & NS \\
\hline \multirow[t]{6}{*}{ Solanaceae } & Datura stramonium & 4-leaf stage & NS \\
\hline & Nicotiana benthamina & \multirow{5}{*}{$\begin{array}{l}10 \text { days after } \\
\text { transplanting }\end{array}$} & NS \\
\hline & Nicotiana glutinosa & & \\
\hline & Nicotiana tabacum (White burley) & & \\
\hline & Nicotiana tabacum (Samsun) & & \\
\hline & Nicotiana rustica & & \\
\hline
\end{tabular}

M-Mosaic; CS-Chlorotic spots; MMo-Mosaic mottling; LB-Leaf blisters; LD-Leaf distortion; VT-Vein thickening; CL-Chlorosis; NS-No symptom

Table 1: Symptoms observed on assay plants through mechanical transmission using the sap of virus infected snake gourd leaves.

\section{Host range}

In host range studies, the virus isolate produced chlorotic local lesions on leaves of C. amaranticolor. The symptoms were observed within 15-17 days of inoculation. The virus isolates caused symptoms on all the tested cucurbitaceous hosts as mosaic and chlorosis in Luffa acutangula, mosaic and leaf blisters in Trichosanthes cucumerina and Lagenaria siceraria, mosaic and leaf distortion in Cucumis sativus, 
Citation: Kumar S, Sankarlingam A, Rabindran R (2014) Characterization and Confirmation of Papaya ringspot virus-W Strain Infecting Trichosanthese cucumerina at Tamil Nadu, India. J Plant Pathol Microb 5: 225. doi:10.4172/2157-7471.1000225

Cucurbita moscheta and Cucumis. No symptom was observed on Carica papaya, Portulaca oleracea, and Chenopodium album. The virus isolates did not induce any symptom on the five fabaceous and six solanaceous hosts. (Table 1 and Figure 2).

\section{Physical properties}

Studies on physical properties of the virus isolates revealed that DEP was 10-2 for the isolate from snake gourd respectively. The severity grade at DEP for the virus was 2.0. TIP the virus isolate was found to be $55^{\circ} \mathrm{C}$ with a severity grade of 1.0 . The LIV was $30 \mathrm{~h}$ at room temperature $\left(28 \pm 2^{\circ} \mathrm{C}\right)$ with a severity grade of 2.0 in both the cases.

\section{Electron microscopy}

Flexuous rod shaped virus particles measuring $750 \times 12 \mathrm{~nm}$ were observed in artificially inoculated leaf samples of snake gourd.

\section{Serology}

Results of DAS-ELISA revealed that the isolates showed a positive

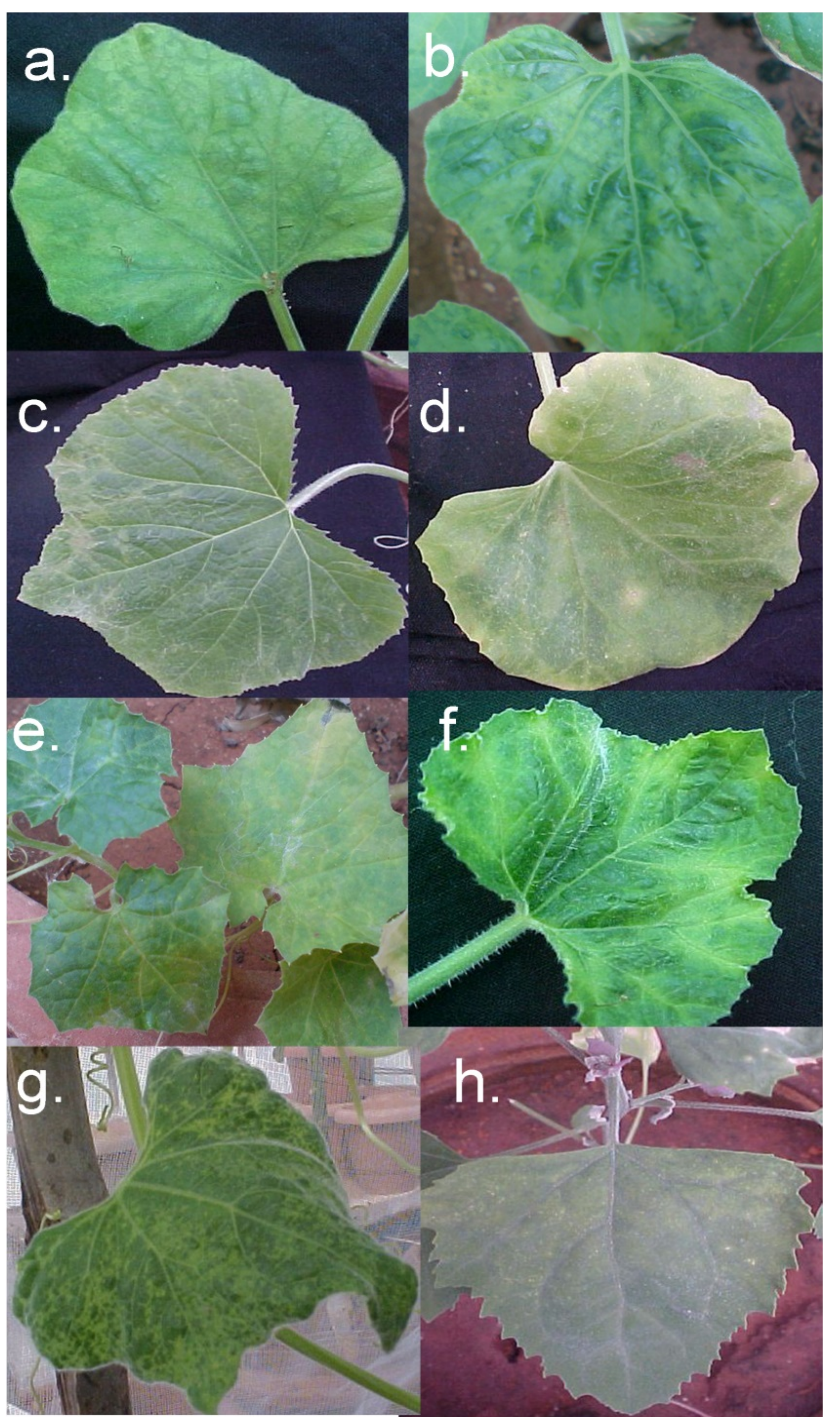

Figure 2: Host range of virus isolated from snake gourd leave, $\mathbf{a}$ and $\mathbf{b}$. Bottle gourd; c. Cucumber; d. Melon; e. Ridge gourd, f. Pumpkin, g. Snake gourd and $\mathbf{h}$. Chenopodium amaranticolor.

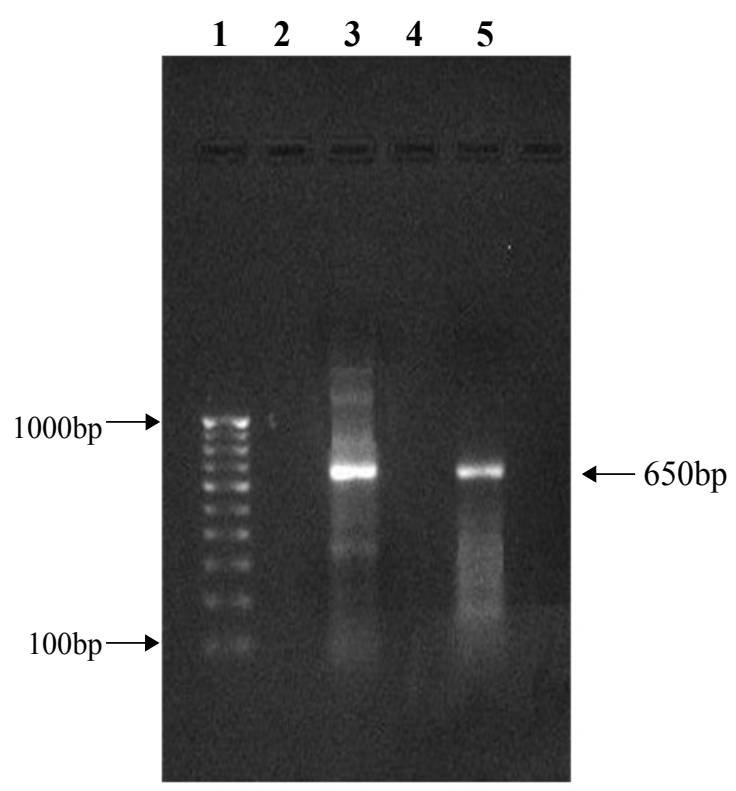

Lane 1- 100bp DNA ladder

Lane 4- Healthy snake gourd

Lane 2-Healthy bottle gourd

Lane 5-Healthy snake gourd

Lane 3- Infected bottle gourd

Figure 3: RT-PCR amplication of coat protein gene of PRSV-W.

reaction with PRSV antiserum. The OD value for infected samples of snake gourd was recorded 0.566 with PRSV antiserum at $405 \mathrm{~nm}$. For PRSV positive samples it was 0.865 . The absorbance values for buffer, healthy samples were 0.116 and 0.204 respectively. There was no reaction with CMV and TSV antisera as the absorbance for healthy and infected samples were in similar range.

\section{Molecular characterization of virus isolates}

Total RNA extracted from infected and healthy leaves of snake gourd exhibited two prominent bands of $5 \mathrm{~Kb}(28 \mathrm{~s}$ rRNA) and 2 $\mathrm{Kb}$ (18s rRNA) and one light band of small RNA. In RT-PCR with the potyvirus specific primers HRP 1, HRP 2, HRP 3 and HRP 4 an amplicon of $\sim 650 \mathrm{bp}$ was obtained. There was no amplification in healthy samples (Figure 3).

\section{Discussion}

As the snake gourd is an important cucurbit grown in the area Tamil Nadu and surrounding. This crop cultivation threatens by mosaic disease which produces mosaic, mosaic mottling, leaf blistering and combinations of these symptoms. To identify and confirm the virus type above study has been conducted as a post-graduation research.

Since the isolates of the present investigation failed to produce symptoms on fabaceous, solanaceous hosts and $H$. annuus, it was concluded that the virus under study was not CMV. The isolates of our study caused systemic symptoms on cucurbits as mosaic mottling and blistering on bottle gourd and snake gourd; mosaic, leaf distortion and leaf blisters on cucumber and melon etc. This is in corroboration with the findings of Roy et al. [8] who observed similar symptoms for the 
Citation: Kumar S, Sankarlingam A, Rabindran R (2014) Characterization and Confirmation of Papaya ringspot virus-W Strain Infecting Trichosanthese cucumerina at Tamil Nadu, India. J Plant Pathol Microb 5: 225. doi:10.4172/2157-7471.1000225

PRSV-W isolate from pumpkin. However, no symptom was observed in his studies on C. amaranticolor while chlorotic local lesions were induced by our isolates in the present research.

Further with the serology analysis isolates of snake gourd from our study showed positive reactions with PRSV antiserum, while no reaction was observed with $\mathrm{CMV}$ and Tobacco streak virus antisera. The PRSV-W isolate of pumpkin and zucchini was found to have close reaction with PRSV antiserum and did not react with ZYMV, CMV and WMV antisera [3].

Finally the RT-PCR of RNA from infected snake gourd samples with potyvirus specific reverse primers HRP1, HRP2, HPR3 and forward primer HRP4 yielded an amplicon of $\sim 650 \mathrm{bp}$ which represents the posterior half CP gene of PRSV. Jain et al. [9] used the same reverse primers with HRP 10, HRP 51 and HRP 52 as forward primers in several combinations to amplify a part of NIb gene, complete $\mathrm{CP}$ gene and UTR of PRSV. A product of $1.7 \mathrm{~Kb}$ was obtained and sequenced. An amplicon of $>1 \mathrm{~Kb}$ representing the $\mathrm{CP}$ and part of NIb gene of PRSV-P was obtained by Sharma et al. [10] with primer HRP 50 and RKJ 3. Sharma et al. [11] obtained a $\sim 850$ bp product from papaya infected with PRSV-P using primers HRP 52 and RKJ 3 that were specific for amplifying the CP gene. Jain et al. [9] in their attempt to clone the CP gene of PRSV-W had observed a 655 bp sequence region which includes the primer sequence of HRP 4.

Based on biological, physical and morphological properties, serology and molecular characterization of the virus isolates which caused mosaic syndrome in snake gourd were concluded as isolates of PRSV-W.

\section{References}

1. Robinsons RW, Decker-Walters DS (1997) Cucurbits. CAB International, Wallingford, UK.

2. Bhargava KS, Joshi RD (1960) Detection of Watermelon mosaic virus in Uttar Pradesh. Current Sci 29: 443-444

3. Dahal G, Lecoq H, Albrechtsen SE (1997) Occurrence of papaya ringspot potyvirus and cucurbit viruses in Nepal Ann appl Biol 130: 491-502.

4. Wang JJ, Yeh SD (1998) Characterization of the Papaya ringspot virus W type isolates collected from different areas of Taiwan by host reactions, immunodiffusion tests and RT-PCR. Plant Prot. Bull 40: 383-395.

5. Cheema SS, Kang SS, Bansal RD (1999) Viral diseases of cucurbitaceous crops and their management. In: Diseases of horticultural crops-vegetables, ornamentals and mushroom. Verma, L. R. and Sharma, R. C.) (Eds.). Indus Publishing Co., New Delhi, India. 257-277.

6. Ali A, Natsuaki T, Okuda S (2004) Identification and molecular characterization of viruses infecting cucurbits in Pakistan. J Phytopath 152: 677-682.

7. Ariyaratne I, Weeraratne WAPG, Ranatunge RKR (2005) Identification of a new mosaic virus disease of snake gourd in Sri Lanka. Ann. Sri Lanka Dept. Agric 7: 13-21.

8. Roy G, Jain RK, Bhat Al, Varma A (1999) Comparative host range and serological studies of papaya ringspot potyvirus isolates. Indian Phytopath. 52: $14-17$

9. Jain RK, Pappu SS, Varma A, Ram RD (1998) Molecular characterization of papaya ringspot potyvirus isolates from India. Ann. Appl. Biol 132: 413-425.

10. Jyoti Sharma, Jain RK, Varma A (2004) Detection of Papaya ringspot virus in naturally infected papaya plants by reverse transcription polymerase chain reaction. Indian Phytopath 57: 237-239.

11. Jyoti Sharma, Jain RK, Ramiah M, Varma A (2005) Natural spread of Papaya ringspot virus to new areas: Occurrence in Coimbatore, Tamil Nadu. Indian Phytopath 58: 245-249. 